ORIGINAL ARTICLE

\title{
NEGLECTED FRACTURE IN MAXILLOFACIAL: CASE SERIES
}

\author{
Rizka Khairiza, \& Muhammad Rizqy Setyarto \\ Division of Plastic Reconstructive and Aesthetic Surgery, Dr. Kariadi Central-General Hospital, Semarang, Indonesia
}

\begin{abstract}
Introduction: Neglected fracture is a condition of fracture that is not handled or mishandled, resulting in a state of delay in treatment, or a worse condition and even a disability. The technical difficulty was associated with a greater incidence of complications and often lead to a suboptimal result. A more precise understanding of maxillofacial fracture's demographic patterns will help healthcare providers manage maxillofacial injuries.

Method: Twenty-nine patients with neglected maxillofacial fractures were registered in the Division of Plastic Reconstructive and Aesthetic Surgery, Dr. Kariadi Central-General Hospital Semarang, January 2015 to December 2018. The collected information included gender, age, etiology, and site of fracture. Some of the cases are presented. Result: Neglected fracture of maxillofacial occurred predominantly in young adults. The male population was more frequently affected $(62 \%)$ - most patients with neglected maxillofacial fractures associated with MVA (84\%). The Mandible was the most common site of the fracture, followed by ZMC.

Conclusion: The possibility of a fracture of Mandible and ZMC or adjacent bones should be considered in any facial trauma, especially related to MVA injury. Early and proper management will provide a better result.

Keywords: Maxillofacial fracture, neglected, delayed

Latar Belakang: Fraktur terabaikan dalah suatu kondisi patah tulang yang tidak tertangani atau salah penanganan, sehingga terjadi keterlambatan pengobatan, atau kondisi yang lebih buruk bahkan kecacatan. Kesulitan teknis dikaitkan dengan insiden komplikasi yang lebih besar dan seringkali mengarah pada hasil yang kurang optimal. Pemahaman yang baik tentang pola demografi fraktur maxillofacial akan membantu penyedia layanan Kesehatan menangani cedera maxillofacial.

Metodologi: Dua puluh Sembilan pasien dengan fraktur maxillofacial terabaikan terdaftar di Divisi bedah plastik rekonstruksi dan estetik RSUP Dr. Kariadi Semarang. Januari 2015 hingga Desember 2018. Informasi yang dikumpulkan meliputi jenis kelamin, usia, etiologi, dan lokasi patah. Beberapa kasus disajikan

Hasil: Fraktur maxiilofacial terabaikan terjadi terutama pada dewasa muda. Populasi pria lebih sering terkena $(62 \%)$ - Sebagian besar pasien dengan fraktur maxillofacial terkait dengan KLL (84\%). Mandibula adalah lokasi fraktur yang paling umum, diikuti oleh ZMC

Kesimpulan: Kemungkinan fraktur mandibula dan ZMC atau tulang yang berdekatan harus dipertimbangkan pada setiap trauma wajah, terutama yang berhubungan dengan cedera KLL. Pengelolaan yang dini dan tepat akan memberikan hasil yang lebih baik.
\end{abstract}

Kata Kunci: fraktur maxillofacial, diabaikan, tertunda

\section{Conflicts of Interest Statement:}

The author (s) listed in this manuscript declare the absence of any conflict of interest on the subject matter or materials discussed. 


\section{INTRODUCTION}

Neglected maxillofacial fracture defined as discontinuity of facial bone structures that are not handled or handled correctly, resulting in a state of delay in treatment usually accompanied by injury in surrounding tissues. Several factors may contribute incidence of neglected fracture, especially in the developing country, such as the availability of proper facilities at the hospital, distant location, and patient refusal for treatment could lead to the patient's neglect. The lack of awareness of the hospital staff to maxillofacial problems may also lead to a misdiagnosis during the early evaluation, resulting in delay or improper handling of facial bone fractures ${ }^{1}$.

In the acute setting of facial trauma, both extraoral and intraoral abnormalities must be examined thoroughly. The patient may present with a visible or palpable deformity and tenderness to palpation of the facial region. Other following signs, such as facial elongation or asymmetry, ocular impairment (diplopia, orbital dystopia, enophthalmos, proptosis, extraocular muscle movement abnormalities), periorbital and maxillary vestibular ecchymosis or edema; epistaxis, skin or lip numbness, etc. Pain may present along with jaw motion. Malocclusion, teeth defect, mucosal bleeding may appear intraorally ${ }^{2}$. These are often accompanied by complex trauma to other areas like the brain and body that threaten the patient's life. Most importantly, patients with trauma to the cranium should undergo a rapid assessment of their mental status and airway compromise. However, these signs may not be as clearly visible in late trauma. The patient may present with several sequels of post-traumatic deformity and disability like malocclusion, visual impairment, facial asymmetry, "dish" face deformity, paresthesia, etc ${ }^{3}$. Computed tomography with 2$\mathrm{mm}$ axial and coronal cuts is recommended as a gold standard for identifying maxillofacial fractures is maxillofacial ${ }^{3,4}$.

The management of facial fractures aims to restore function and aesthetic reconstruction. However, the difficulty of surgery may increase if delay allows osseous callus formation and soft tissue fibrosis. The technical difficulty has been suggested by some to be associated with a greater incidence of complications ${ }^{5}$. Numerous complications may also arise from adjacent organs related to fracture sites, which may or may not be corrected because the reconstruction is too late ${ }^{6}$.

In this context, early injury recognition and repair have great importance in achieving satisfactory anatomic reconstruction. A more precise understanding of maxillofacial fracture's demographic patterns will help healthcare providers manage maxillofacial injuries. Unfortunately, the epidemiological studies of maxillofacial fractures in Indonesia are still minimal, moreover, the neglected ones. This retrospective study aimed to describe the characteristics of a patient with the neglected treatment of maxillofacial fractures. We also present a few cases that may help provide a bigger picture in managing patients' neglected maxillofacial fractures.

\section{METHODS}

This retrospective study involved 29 patients with facial fractures registered in the Division of Plastic Reconstructive and Aesthetic Surgery, Dr. Kariadi Central-General Hospital Semarang, between January 2015 and December 2018. The inclusion criteria were patients who had fractures of the facial bones presented to treat their maxillofacial injuries at least four weeks after injury. Patients might present with a single or simultaneous fracture of facial bones had to have at least one site. The data collected from medical records, including gender, age, etiology, and fracture site, are presented using frequency tabulation. Some of the cases are presented below.

\section{RESULTS}

In this study, there were 29 patients with neglected fractures in 51 locations of fracture. This study discovered that out of 29, 18 patients $(62 \%)$ were males, while 11 were females $(38 \%)$. Patients had a variative range of ages from 6 to 48 years with a mean of 24,83 years. The majority of patients fell within the age range of 18-27 years $(56 \%)$. The dominant etiology was motor vehicle accident (MVA), accounted for $84 \%$.

Regarding the site of the fracture, fractures or ZMC accounted for $21 \%$ among midface fractures. Followed by maxilla fractures and 
nasal fracture, both $12 \%$. A total of $41 \%$ of mandible fractures were recorded. The condyle and subcondyle regions counted for $17 \%$ out of $41 \%$ as the most location, followed by angle region $(8 \%)$, body $(6 \%)$, dentoalveolar $(6 \%)$, and symphysis/parasymphisis regions $(4 \%)$.

Table 1. Description

\begin{tabular}{|c|c|}
\hline Characteristic & Participant \\
\hline Number of patients & $29(100 \%)$ \\
\hline \multicolumn{2}{|l|}{ Gender (\%) } \\
\hline Male & 62 \\
\hline Female & 38 \\
\hline \multicolumn{2}{|l|}{ Age } \\
\hline Mean & 24,83 \\
\hline \multicolumn{2}{|l|}{ Age categories (\%) } \\
\hline$<18$ & 18 \\
\hline $18-27$ & 56 \\
\hline $28-37$ & 13 \\
\hline $38-47$ & 13 \\
\hline \multicolumn{2}{|l|}{ Mechanism of injury (\%) } \\
\hline MVA & 84 \\
\hline Fall & 4 \\
\hline Assault & 3 \\
\hline Sport & 7 \\
\hline Misc. & 2 \\
\hline \multicolumn{2}{|l|}{ Site of fracture (\%) } \\
\hline \multicolumn{2}{|l|}{ Upper facial } \\
\hline Frontal & 6 \\
\hline \multicolumn{2}{|l|}{ Midfacial } \\
\hline NOE & 8 \\
\hline Nasal & 12 \\
\hline $\mathrm{ZMC}$ & 21 \\
\hline Maxillary & 12 \\
\hline \multicolumn{2}{|l|}{ Lower facial/Mandible } \\
\hline Symphysis/Parasymphisis & 4 \\
\hline Body & 6 \\
\hline Dentoalveolar & 6 \\
\hline Angle & 8 \\
\hline Condyle/Subcondyle region & 17 \\
\hline
\end{tabular}

$\mathrm{ZMC}=$ Zygoma-maxillary-complex

\section{CASE PRESENTATION}

\section{Case 1}

A 27-years-old male presented to our institution with facial asymmetry and slight right eye lagophthalmos without eyeball entrapment (Figure 1). He was injured in a motor vehicle accident two years ago but refused for surgical treatment from a district hospital surgeon. On the examination, asymmetrical malar eminences were confirmed with complete ossification of the underlying bone in the former site of the right
ZMC fracture, which was seen from 3D CT reconstructions imaging. Re-fracture and boneimplant placement were first planned to be done but were later canceled due to the patient's refusal. To correct the asymmetrical cheekbone and eye closure, a solid silicone implant decided to be put through an infraciliar incision to create malar contour (Figures 2 and 3 ).
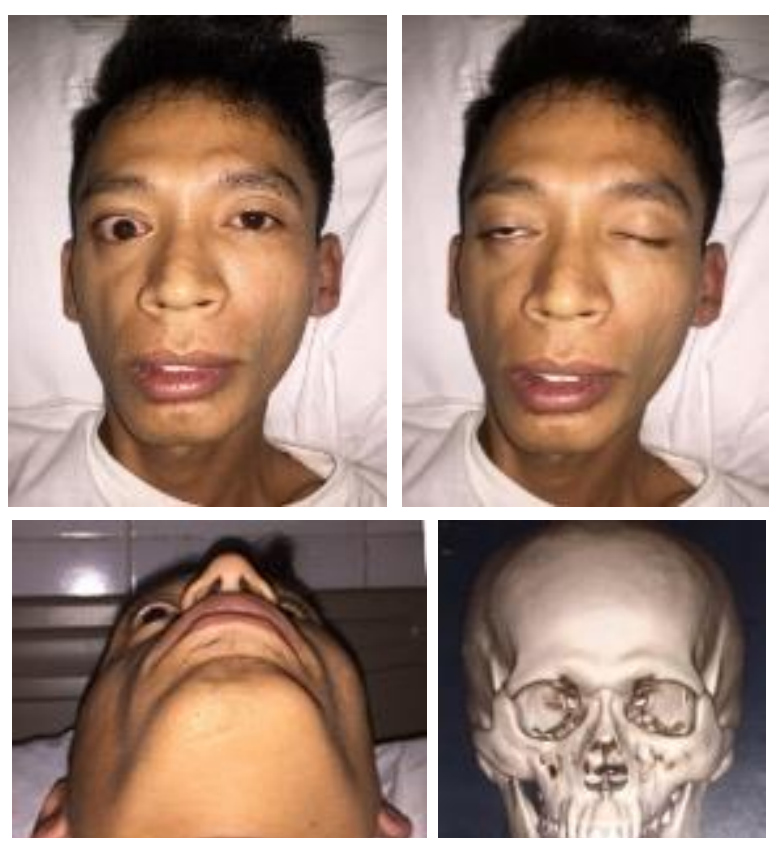

Figure 1. Clinical examination exhibited dystopia and lagophtalmos of right eye; 3D reconstruction image exhibited union of malar bone.

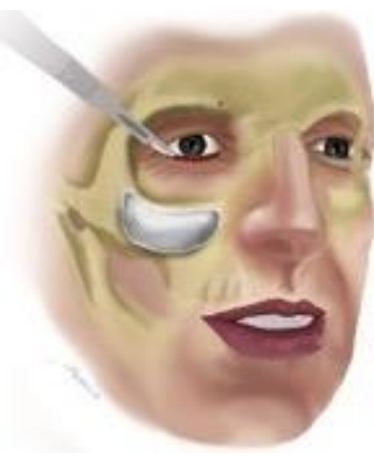

Figure 2. Design of surgical approach to malar implant
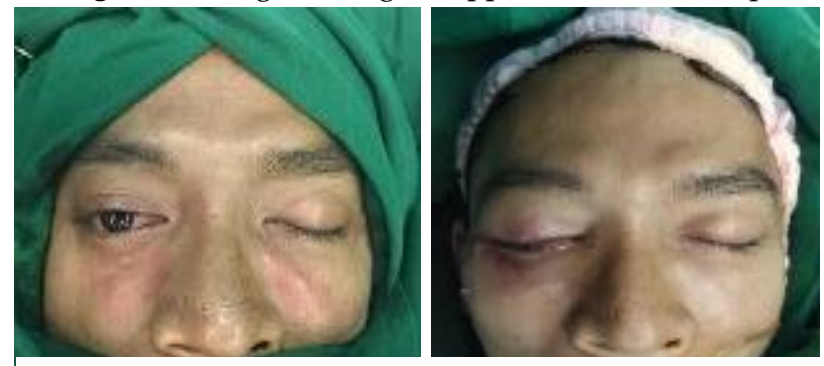

Figure 3. Pre- (left) and post-(right) malar correction. 

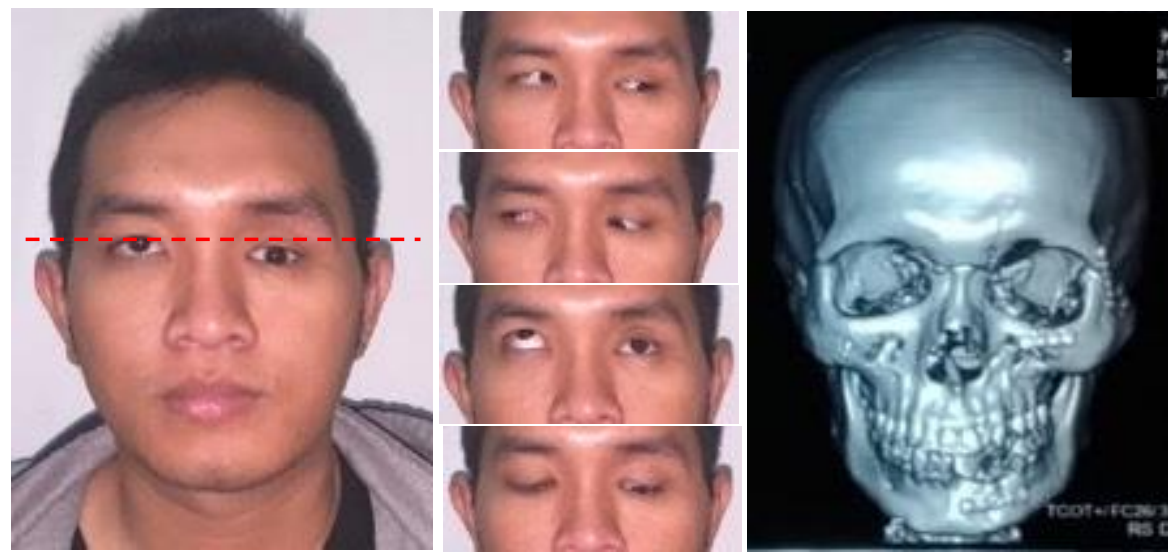

Figures 4. Clinical examination exhibited dystopia along with restriction of superior movement of left eye ball; 3D reconstruction image exhibited multiple internal fixation plate.
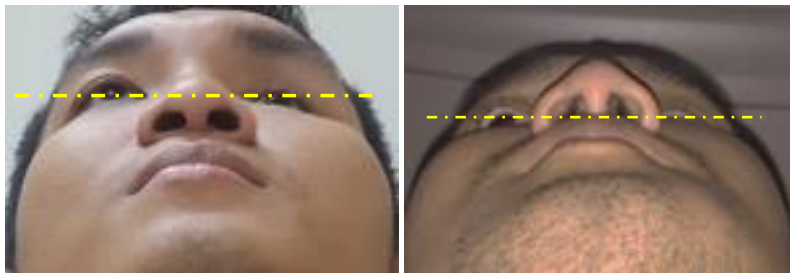

Figures 5. Pre- (left) and post-(right) malar correction.

\section{Case 2}

A 27-years-old male presented with a history of pan facial fractures (Figures 4). He was injured in a traffic accident a year ago and had undergone a reduction for the placement of the internal plate and interdental wiring by a surgeon at a district hospital. He was referred from the Division of Ophthalmology with complained of doubled vision and asymmetrical eye position. On the physical examination, there was prominent asymmetry of malar bone. This came along with dystopia and left superior rectus ocular muscle entrapment. On the 3D CT reconstructions imaging, multiple internal fixation plates were seen at several parts.

We re-fractured the left ZMC bone to reestablished the correct projection of malar eminence and then replaced the internal fixation plate after. Muscle entrapment was released. There were some appearance improvements, including improved orbital dystopia and corrected facial asymmetry (Figures 5). However, the vision could not be corrected because the reconstruction was too late.

\section{Case 3}

A 35-years-old female presented with complained of premature bite due to a bilateral subcondyle fracture (Figures 6). She was injured in a traffic accident four weeks before presented but refused to be carried to the nearest hospital. Later she complains inability to chew properly. She also felt pain along with mild stiffness in the area of right TMJ. Intraoral examination revealed an anterior open bite malocclusions condition. In the multi sliced CT-scan, complete bilateral subcondyle fractures were seen with displacement and medial dislocation of the right condyle (Figures 7). The left subcondyle area exhibited great alignment, which started to unite.

We first planned to reconstruct the right condyle neck to reestablishes the proper height of the ramus and facial projection and places the occlusal table in the proper state. However, to avoid extensive approach due to massive fibrotic tissue formation and prevent local nerve and vascular injury, the fractured fragment was decided to be just taken out, followed by the placement of maxillomandibular wire to achieve normal occlusion.

\section{DISCUSSION}

Maxillofacial fractures have now become a public health issue worldwide. These injuries are one of the most common issues dealt with by plastic surgeons in their professional practice. The epidemiology may vary widely in every country. Several factors may contribute to the 

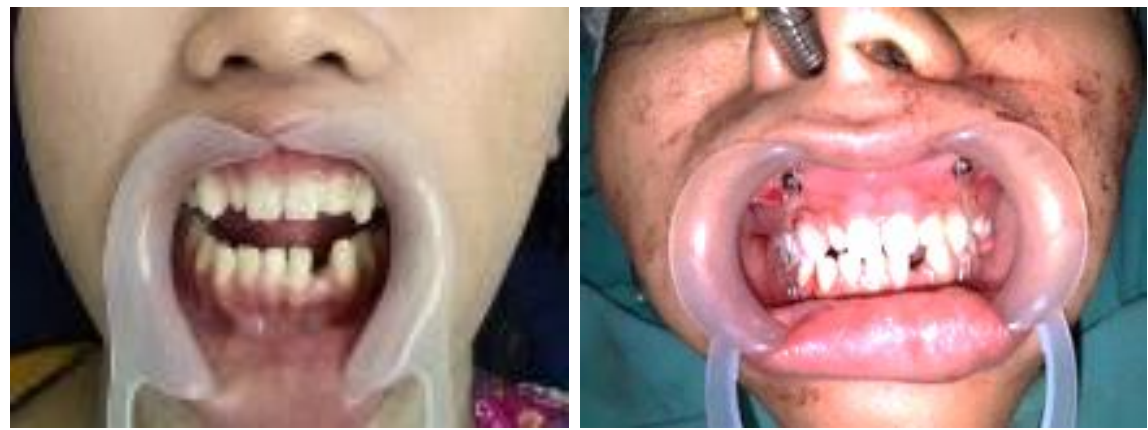

Figures 6. Pre- (left) and post-(right) surgery occlusion state
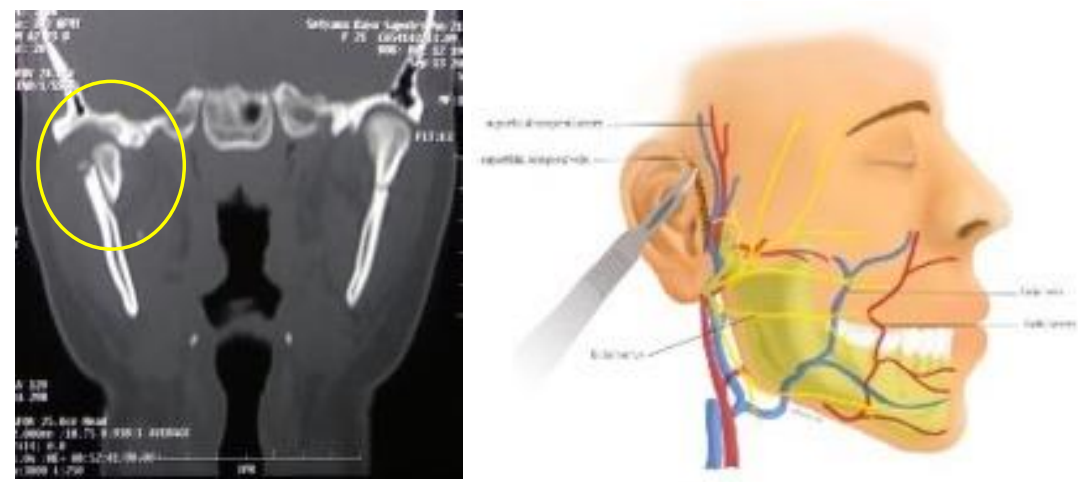

Figures 7. CT imaging exhibited completed fracture with medial displacement of right subcondylar neck; design of surgical approach to condylar expose region.

incidence and etiology of maxillofacial fracture, including geographical location, culture, socioeconomic background, population density, transportation, and traffic legislation $7-9$.

Our mini-study revealed that the most commonly affected maxillofacial fracture was 18 to 27 years old, similar to most studies in the literature from developing countries. Subhashraj et al. also observed that those between 20 and 29 years of age were more commonly affected in Chennai, India7; Fasola et al. reported 21 to 30 years were the most affected ages in Nigeria 8 . This might be due to the higher social activity than children, middle-aged, and elderly persons. Moreover, people in this decade of age are more active, energetic, take active participation in dangerous exercises and sports activities, involved in high-speed driving, less commitment to traffic regulations, and are mostly involved in violence 9 . The male population was more frequently affected, accounting for $62 \%$. The male-to-female ratio was almost attaining a 2:1. This fact may also be attributed that the female is less frequently exposed to fight, traffic, massive works, and sports. Females also tend to be more careful than males, makes them least susceptible ${ }^{10}$.

The common causes of maxillofacial trauma are road crashes, assaults, sports, occupationalrelated injuries, and falls ${ }^{7}$. Our study found that $82 \%$ etiology of injury were MVA, which was consistent with several previously conducted studies in some developing countries, such as India, Nigeria, Iran, United Arab Emirate, and china ${ }^{7-9,11-13}$. Unlike in most developed countries where assaults/interpersonal violence has replaced most road traffic crashes as the major cause of the injuries ${ }^{10,14}$. Road traffic accidents occur mainly due to the driver's recklessness and negligence, poor maintenance of vehicles, often driving under the influence of alcohol or drugs, and a complete disregard of traffic laws ${ }^{9-13}$.

The anatomic location and pattern of facial fractures are determined by the mechanism of injury and direction of impact. The most commonly fractured bones in this study were the Mandible, followed by the ZMC. This is 
consistent with findings in developing countries by some other studies $9,12-14$.

Statistically, as reported, fractures of mandibles $(31 \%)$ are the most common among facial fractures. Mandible fracture may be found in association with injury or displacement of the teeth or may occur in isolation ${ }^{15}$. As it is the most common fractures of the face, the presence of mandible fractures in any facial trauma should not be slipped. In the last ten years, computed tomography has replaced panoramic tomography as the gold standard for imaging patients with suspected mandible fractures ${ }^{2}$. However, these are not accessible to many health care facilities in the developing country. Physical examination, together with simple screening tests, like the tongue blade test (TBT), can help the physician narrow their differential diagnosis more quickly in real-time. A study by Caputo et al. demonstrated that the TBT is a useful clinical tool to help rule out a mandible fracture, with an overall accuracy of $82 \%$ as the likelihood ratio is 0.0716 .

Regarding the distribution of mandibular fractures, $17 \%$ out of $31 \%$ was observed in the condylar and subcondyle regions. A high incidence of mandibular condyle fracture is attributable to the mandibular ramus's binding with high stiffness and mandibular condyle head with low stiffness, which is generally caused by an indirect force delivered to the mandibular condyle head ${ }^{17}$. In particular, as mandibular condyle fracture may cause long-term complications such as mandibular growth and functional disorders and chronic temporomandibular joint (TMJ) complication, more caution should be given ${ }^{18}$.

The orbitozygomaxillary complex which involved in $21 \%$. The zygoma, central to standard malar projection, plays a significant role in maintaining the face's cosmetic and functional aspects. (18) After the blunt impact that causes the characteristic ZMC fracture pattern and isolates the zygoma from the rest of the facial skeleton, the pull of the masseter muscle, which extends from the zygoma to insert on the ramus of the Mandible, can cause an additional rotational deformity of the zygoma and malar depression. Restoring a patient's premorbid facial contour is a chief goal of the surgeon, who pays particular attention to reestablishing accurate alignment across the zygomaticofrontal and zygomaticomaxillary articulations, inferior orbital rim, and lateral orbital wall ${ }^{19}$.

Complications arising from facial fractures may be particularly debilitating due to the face's functional and cosmetic role, which often adds significant emotional and economic disabilities 5,13. Infected fracture, including abscess and osteomyelitis, has been the marked fear related to delayed treatment of the neglected facial fracture ${ }^{20}$. Other following complication may arise from a neglected facial fracture as well as chronic pain, sensory abnormalities, facial disfigurement, trismus, malocclusion, dental and speech disabilities, and ophthalmologic disability such as eye disfigurement, visual loss, diplopia, and retrobulbar hematoma6,19. Neglected facial fracture may also increase the length of hospital stay, days in the ICU, and days on a ventilator; the need for revision surgery; weight loss; prolonged rehabilitation; death ${ }^{5}$.

The delay between injury and treatment for facial fractures can be divided into the following groups: delay between injury and presentation to health care, the delay between presentation to health care and diagnosis, and the delay between diagnosis and treatment. Factors that influence each group may differ ${ }^{2}$. On the other hand, delaying facial reconstruction is sometimes intentionally left for a second stage operation due to certain conditions, including the presence of concomitant injuries (e.g., cerebral injuries, thoracic injuries, abdominal injuries). The relevance of delay from injury to treatment is commonly disputed amongst surgeons and works of literature. Prominent surgeons have previously advocated delays from injury to surgery of no more than 24,48 , and 72 hours, retrospectively ${ }^{1,5}$.

However, healthcare providers who take care of these patients have to understand the related physical examinations. Any misdiagnosis or incorrect reconstruction of the pre-injury anatomy can cause post-traumatic deformities that can lead to serious complications ${ }^{6}$. Early diagnosis and management of any facial injury are essential to prevent late treatment and possible permanent disfigurement ${ }^{1,5,6}$. Intuitively, delaying the treatment of facial fractures could increase the risk of infection, the likelihood of technical difficulties, and patients' discomfort.

In the middle third of the face, an excellent blood supply, combined with the absence of bony mobility in most cases, will result in an excellent 
bony union, even if it is not in good alignment. However, the Mandible situation is different because vascularity is not as good, and the mobility of the jaw may delay or hinder union ${ }^{1,3}$. all of which makes delayed treatment very difficult $^{3}$. Moreover, even with anatomic bony repositioning, secondary or late reconstruction precludes a standard bone-soft tissue interface due to thickened, inelastic tissue ${ }^{2}$. For these reasons, precise diagnosis and proper treatment of the facial fracture is mandatory, whenever possible.

One of our study's significant limitations is that our sum of the case is too small to carry a representative paper for epidemiological characteristics of neglected fractures of maxillofacial. Like other retrospective studies, this analysis may be subject to information bias due to inaccurate original examination and incomplete records and documentation. However, the results provide essential information necessary for developing and evaluating preventative measures to reduce the frequency of neglected fractures of maxillofacial in Indonesia, where similar events are often found though are not scientifically reported.

\section{CONCLUSION}

The possibility of a fracture of Mandible and ZMC or adjacent bones should be considered in any facial trauma, especially related to MVA injury. An accurate diagnosis can reduce the incidence of neglected maxillofacial fracture. Early and proper management will provide a better result and minimize physical and socioemotional complications.

\section{Correspondence regarding this article should be addressed to: \\ Muhammad Rizqy Setyarto \\ Division of Plastic Reconstructive and Aesthetic Surgery, \\ Dr. Kariadi Central-General Hospital, Semarang, 50244, \\ Indonesia \\ E-Mail: riza_prihadi@yahoo.com}

\section{REFERENCES}

1. Zachariades N, Papavasilliou D, Papademetriou I, Koundouris I, Rapidis A. Neglected fractures of the facial bones.
Journal of Maxillofacial Surgery. 1984;12:3640.

2. Chukwulebe S, Hogrefe C. The Diagnosis and Management of Facial Bone Fractures. Emergency Medicine Clinics of North America. 2019;37(1):137-51.

3. He D, Zhang Y, Ellis E. Panfacial Fractures: Analysis of 33 Cases Treated Late. Journal of Oral and Maxillofacial Surgery. 2007;65(12):2459-65.

4. Viozzi CF. Maxillofacial and Mandibular Fractures in Sports. Clinics in Sports Medicine. 2017;36(2):355-68.

5. Hurrell MJL, Batstone MD. The effect of treatment timing on the management of facial fractures: a systematic review. International Journal of Oral and Maxillofacial Surgery. 2014;43(8):944-50.

6. Wahdini SI, Dachlan I, Seswandhana R, Hutagalung MR, Putri IL, Afandy D. Neglected orbitozygomaticomaxillary fractures with complications: A case report. International Journal of Surgery Case Reports. 2019;62:35-9.

7. Subhashraj K, Nandakumar N, Ravindran C. Review of maxillofacial injuries in Chennai, India: A study of 2748 cases. British Journal of Oral and Maxillofacial Surgery. 2007;45(8):637-9.

8. Fasola AO, Nyako EA, Obiechina AE, Arotiba JT. Trends in the characteristics of maxillofacial fractures in Nigeria. Journal of Oral and Maxillofacial Surgery. 2003;61(10):1140-3.

9. Mijiti A, Ling $W$, Tuerdi M, Maimaiti A, Tuerxun J, Tao YZ, et al. Epidemiological analysis of maxillofacial fractures treated at a university hospital, Xinjiang, China: A 5-year retrospective study. Journal of CranioMaxillofacial Surgery. 2014;42(3):227-33.

10. Rashid A, Eyeson J, Haider D, van Gijn D, Fan $\mathrm{K}$. Incidence and patterns of mandibular fractures during a 5-year period in a London teaching hospital. British Journal of Oral and Maxillofacial Surgery. 2013;51(8):794-8.

11. Samieirad S, Aboutorabzade M, Tohidi E, Shaban B, Khalife H, Hashemipour M, et al. Maxillofacial fracture epidemiology and treatment plans in the Northeast of Iran: A retrospective study. Med Oral. 2017;0-0.

12. Azad A, Azad A, Dubey A. Retrospective study of prevalence of maxillofacial fractures in Bhopal, Madhya, Pradesh population. 
Journal of Advanced Medical and Dental Sciences Research. 2016;4(1):5.

13. Al-Khateeb $\mathrm{T}$, Abdullah FM. Craniomaxillofacial Injuries in the United Arab Emirates: A Retrospective Study. Journal of Oral and Maxillofacial Surgery. 2007;65(6):1094-101.

14. Boffano P, Kommers SC, Karagozoglu KH, Forouzanfar T. Aetiology of maxillofacial fractures: a review of published studies during the last 30 years. British Journal of Oral and Maxillofacial Surgery. 2014;52(10):901-6.

15. Murray JM. Mandible Fractures and Dental Trauma. Emergency Medicine Clinics of North America. 2013;31(2):553-73.

16. Caputo ND, Andaleeb R, Christoper S, Nathan M. Re-Evaluating the Diagnostic Accuracy of the Tongue Blade Test: Still Useful as a Screening Tool for Mandibular Fractures? The Journal of Emergency Medicine. 2013;45(1):8-12.

17. Choi K-Y, Yang J-D, Chung H-Y, Cho B-C. Current Concepts in the Mandibular Condyle Fracture Management Part I: Overview of Condylar Fracture. Arch Plast Surg . 2012;39(4):291.

18. Żmudzki J, Panek K, Chladek G, Adamiak M, Lipinski P. Finite Element Analysis of Adolescent Mandible Fracture Occurring during Accidents. Medicine \& pharmacology; 2018.

19. Kim JJ, Huoh K. Maxillofacial (Midface) Fractures. Neuroimaging Clinics of North America. 2010;20(4):581-96.

20. Anggayanti NA, Sjamsudin E, Sylvyana M, Rizki KA. The management of osteomyelitis at Mandible due to neglected fracture: A case report from Hasan Sadikin, BandungIndonesia. Bali Med J. 2018. 